虫垂粘液囊胞腺腫を契機に発見された小腸サルコイドーシスの 1 例

横浜掖済会病院外科

長田俊一高橋徹也福島忠男高橋利通

症例は 80 歳，男性. 現病歴として平成 12 年 9 月より腹痛が出現し，前医を受診. 大腸 尰瘍の診断で当科紹介入院となった。触診上, 右下腹部に $5 \mathrm{~cm}$ 大の弾性のある腫瑒を触 知. CT 上内部均一で low density の腫瘤を認め, 回盲部腫煬の診断で手術を施行した. 開腹すると虫垂原発の腫瘤を認めた。 また,バウヒン弁より約 $70 \mathrm{~cm}$ の回腸に全周性の線 状潰瘍を認め, 回盲部切除を施行した。病理診断は虫垂粘液豪胞腺腫と小腸サルコイド ーシスであった。

小腸サルコイドーシスの報告は稀であるため, 報告例を集計し, 文献的考察を加え報 告する.

索引用語：小腸サルコイドーシス，虫垂粘液惑胞腺腫

はじめに

サルコイドーシスは全身性疾患で, あらゆる臟器に 肉芽腫性病変を形成しうる原因不明の疾患であるが, 小腸病変は稀である。かれわれは，腹痛と腹部腫瘤を 主訴とした虫垂粘液囊胞腺尰の手術を契機に発見され た小腸サルコイドーシスの 1 例を経験したので, 文献 的考察を加えて報告する.

$$
\text { 症例 }
$$

患 者：80歳, 男性.

主 訴: 腹痛.

家族歴：特記すべき事項なし。

既往歴：特記すべき事項なし.

現病歴: 平成 12 年 9 月より腹痛と腹部腫瘤に気付 き,前医を受診し,大腸腫場の診断で当科紹介となった。

入院時現症：身長 $157 \mathrm{~cm}$, 体重 $55 \mathrm{~kg}$, 体温 $36.0^{\circ} \mathrm{C}$, 血厌 $160 / 80 \mathrm{mmHg}$, 脈拍 $78 /$ 分, 整, 呼吸数 $12 /$ 分. 顐 血および黄㾝なし．胸部理学的所見に異常なし．触診 上, 右下腹部に $5 \mathrm{~cm}$ 大の弾性のある腫㷎を触知する も反跳痛なし.

入院時検查所見：血液および生化学検査では異常所 見なし。

胸部 $\mathrm{X}$ 線検查 : 両側肺門部のリンパ節腫脹は認め

2002 年 1 月 7 日受付 2002 年 2 月 18 日採用

〈所属施設住所〉

テ231-0036 横浜市中区山田町 1-2
なかった(図 1 a).

注腸造影検查：上行結腸に壁压排像を認め, 壁外性 の腫瘤が疑われた。また, 盲腸, 回腸は造影されなか つた（図 1 b).

腹部 CT 検査：上行結腸の内側に接して辺縁平滑明 瞭かつ内部均一で low density を呈した卵円型腫嘴を 認めた(図 2). 以上より，origin および性状は不明な るも回盲部腫場の診断で10月12日に開腹手術を行った。

手術所見：回盲部に $7 \times 5 \mathrm{~cm}$ の哓状の腫痛を認 め, 回腸が巻き込まれて一塊となっていた。また,バ ウヒン弁より約 $70 \mathrm{~cm}$ の回腸に狭窄を認めた。内容を 漏出させないように回盲部切除を施行した。

摘出標本所見：回盲部の腫瘤は腫脹した虫垂であ り，それを開くとゼラチン様の粘液を認めた（図 3 )。 また, バウヒン弁より約 $70 \mathrm{~cm}$ の回腸に全周性の線状 潰湯を認めた（図 4 )。

病理組織学的所見：虫垂は, 高円柱状でやや核の濃 染はあるものの異型像は認めず, 粘液哓胞腺腫と考え られた(図 5 )。回腸の線状潰場は, 粘膜下組織, 固有 筋層, 漿膜下組織に多数のリンパ球浸潤を伴う類上皮 細胞の結節を認め, 非乾酪性の肉芽腫であることから， サルコイドーシスと診断された（图6）.

$$
\text { 考察 }
$$

サルコイドーシスは全身に類上皮性肉芽腫を形成す る原因不明の疾患であり, 肺外病変としては眼, 皮虐, 心, 神経, 肝, 脾, 骨, 骨髄, 筋, 耳下腺, 消化管等 


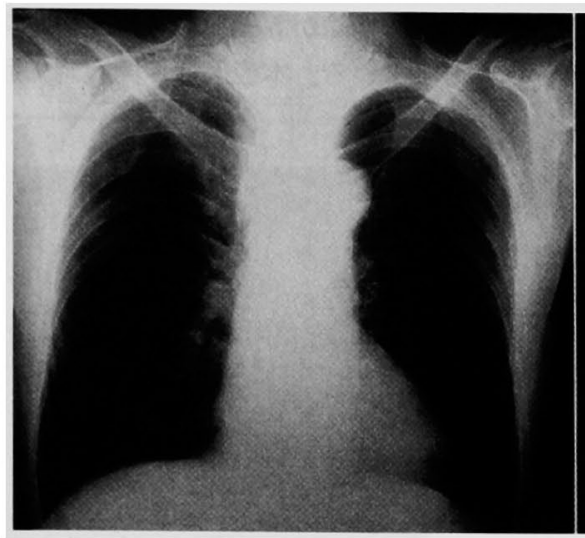

a

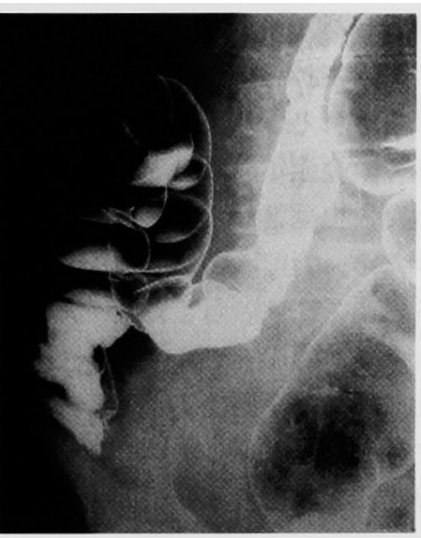

b

図 1 a 胸部X線検查 : 両側肺門部のリンパ節腫脹は認めなかった。

b 注腸造影検査：上行結腸に壁圧排像を認め, 壁外性の腫瘤が疑われた。

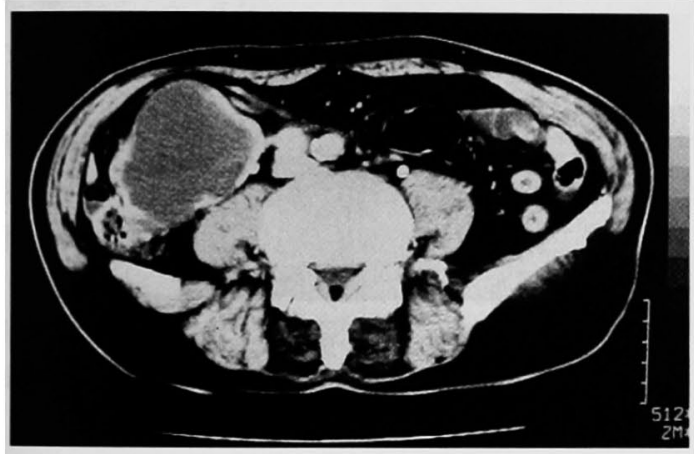

图 2 腹部 CT 検查：上行結腸の内側に接して辺縁平滑 明瞭かつ内部均一で low density を呈した卵円型腫瘤 を認めた。

\section{が報告されている1．}

消化管は胃病変が比較的多いが, 下部腸管にサルコ イドーシスを認めた症例は非常に少ない.1963年に Mayock らはサルコイドーシスに関する自験および 文献集計 287 例中 2 例 $0.7 \%$ に下部腸管のサルコイドー シスを認めると報告している。

表 1 に筆者の調べえた範囲内で記載の明らかな小腸 サルコイドーシス報告例を集計したが自験例を含め15 例（うち本邦報告例は 6 例）認めるのみであった。年 齢は21歳から80歳までばらつきがあり，20代，40代に 多かった。性差は認められなかった。主な臨床症状と しては難治性下痢, 腹痛, 体重減少, 全身倦意感, 腹 部腫瘤と下血であった，小腸病変を有するサルコイド ーシスでは，必ずしも肺病変が証明されておらず，肺 外病変としては, 肝, 脾, 胃, 腹部リンパ節が多かっ

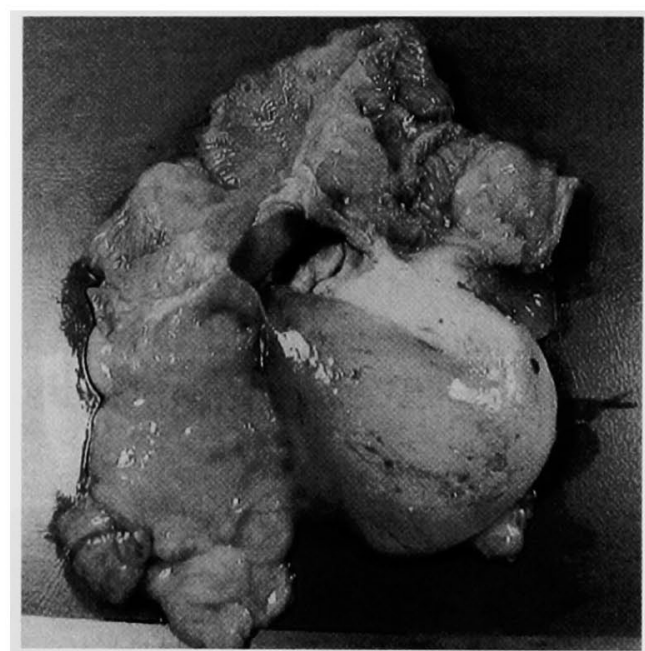

図 3 摘出標本所見 : 虫垂を開くとゼラチン様の 粘液を認めた。

た。本症例については，術後検索においてとくに小腸 外病変は認めなかった。肉眼所見は粘膜の浮腫, 易出 血性, 肥厚化, 顆粒状変化, 潰煌形成等の変化が認め られるが”，本症例では線状潰煌であった。

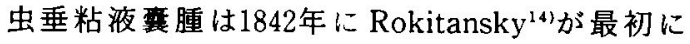
hydrops processus vermiformis として報告し, 1984 年の笠原ら ${ }^{15)}$ の集計によると 400 余例が報告されている。

組織学的に非腫瘍の貯留亯胞 (simple mucocele), 良性腫湯の粘液豪胞腺腫 (mucinous cystadenoma), 覀性腫瘍の粘液烡胞腺癌 (mucinous cystadenocarcinoma）の 3 種に分類される. 
今回われわれが経験した，腫場性で良性である虫垂 粘液亯胞腺腫について, 長谷川ら ${ }^{16)}$ が集計したところ, 53例が論文として報告されていた，性別は男性20例， 女性33例と女性に多く, 発症年齡は26〜84歳で, 平均 年齢は63.8歳であった。虫垂粘液赛胞腺腫は特徴的な 症状や所見が少ないため，術前診断が困難な疾患の一 つであり，53例中 5 例のみ術前䛦断しえた。また，癌 との鑑別が問題となるが，樋田ら ${ }^{171}$ は虫垂粘液豪胞の 良・悪性を鑑別することは迅速冷凍切片による病理診 断を行っても極めて困難であるとしている. 術式は回 盲部切除20例, 虫垂切除13例, 右半結腸切除10例, 盲

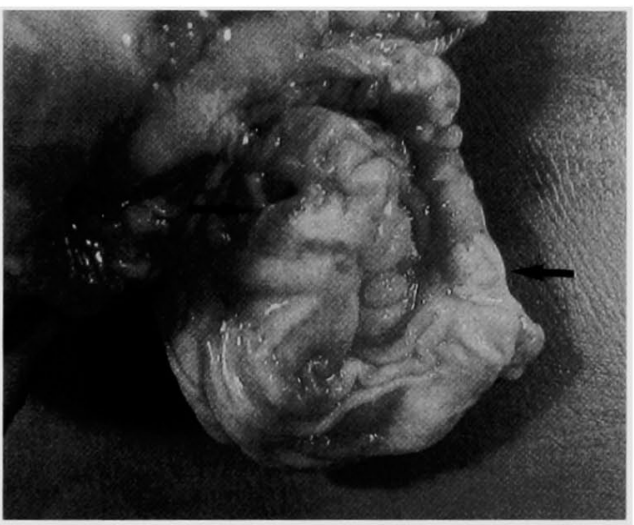

図 4 摘出標本所見：回腸に全周性の線状溞瘍を 認めた。
腸部分切除が 5 例であり，回盲部切除が一番多かった としている，本症例は，開腹時に回盲部の腫瘤に回腸
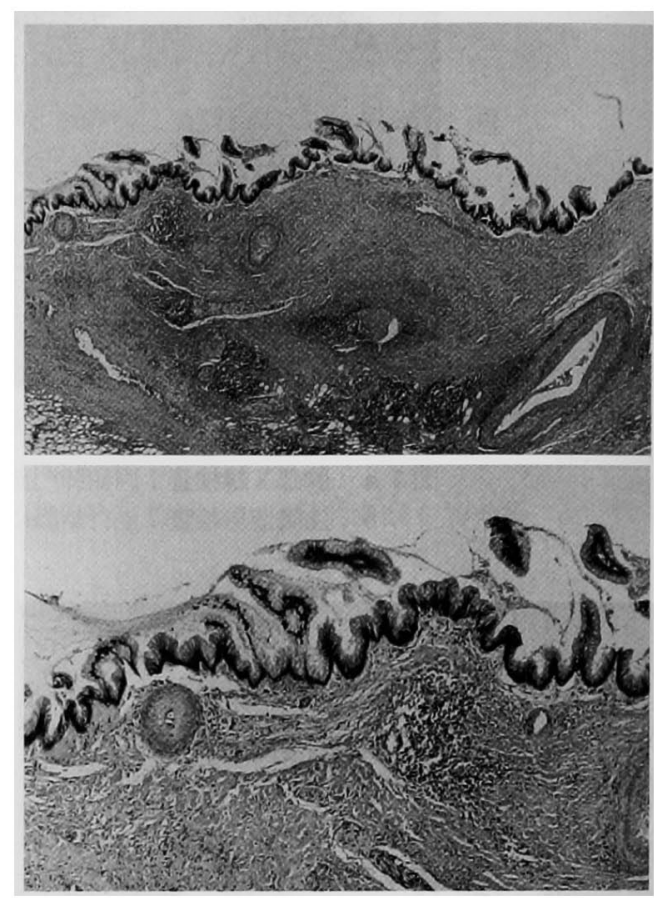

图 5 病理組織学的所見：虫垂は，高円柱状でやや 核の濃染はあるものの異型像は認めず，粘液毫胞 腺腫と考えられた $(\mathrm{HE}, \times 4, \times 10)$.

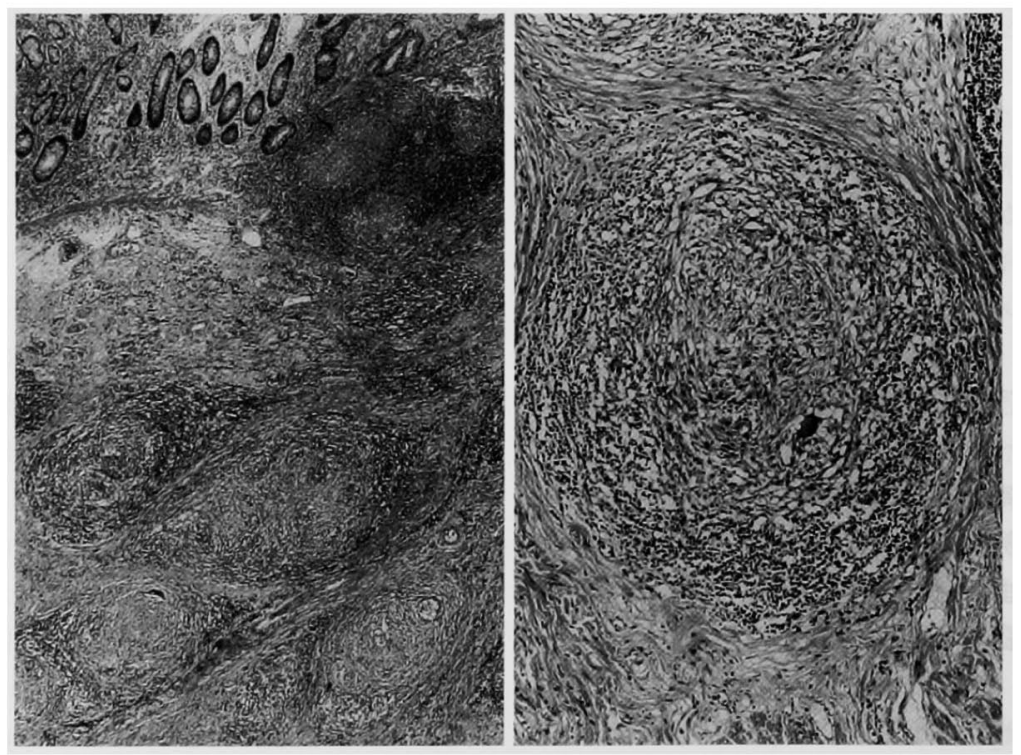

図 6 病理組織学的所見：回腸の線状潰瘍は, 粘膜下組織, 固有筋層, 漿膜下組織 に多数のリンパ球浸潤を伴う類上皮細胞の結節を認めた（HE, $\times 4, \times 10 ）$. 
表 1 小腸サルコイドーシスの報告例

\begin{tabular}{|c|c|c|c|c|c|c|c|c|c|}
\hline No & 年 & 著者 & 年齢 & 性別 & 主訴 & 発症部位 & 肺病変 & 診断方法 & 小腸外病変 \\
\hline 1 & 1945 & Watson $\mathrm{CJ}^{3)}$ & 21 & $\mathrm{~F}$ & diarrhea & unspecific & - & resection & \\
\hline 2 & 1945 & Watson $C J^{3)}$ & 25 & F & diarrhea & ileum & - & resection & \\
\hline 3 & 1961 & Becker WF' & 24 & $\mathrm{~F}$ & abdominal cramps & unspecific & - & resection & spleen, liver, omentum \\
\hline 4 & 1961 & Becker WF" & 39 & $\mathrm{~F}$ & enlargement of the abdomen & unspecific & + & biopsy & kidney, liver, skin, spleen, LN \\
\hline 5 & 1962 & Delor $\mathrm{CJ}^{3)}$ & 27 & M & nausea and vomiting & unspecific & - & biopsy & stomach, pancreas, liver, LN \\
\hline 6 & 1972 & Miyamoto $\mathrm{C}^{6}$ & 61 & $F$ & general edema & unspecific & + & autopsy & stomach, liver, spleen. \\
\hline 7 & 1980 & Matsuda $Y^{7}$ & 55 & $\mathrm{~F}$ & abdominal tumor & ileum, ileocecum & - & resection & stomach, liver, abdominal LN \\
\hline 8 & 1883 & Sugiura $\mathrm{H}^{\mathrm{B})}$ & 42 & M & epigastric pain & ileum, ileocecum & - & resection & stomach, abdominal LN \\
\hline 9 & 1984 & Sprague $R^{g}$ & 60 & $\mathrm{~F}$ & diarrhea & jejunum & + & biopsy & thyroid, liver, spleen, stomach, abdominal LN \\
\hline 10 & 1985 & Itoh $T^{101}$ & 74 & M & hematochezia & jejunum & + & resection & \\
\hline 11 & 1988 & Bulger $\mathrm{K}^{(1)}$ & 48 & M & abdominal pain & ileocecum & + & autopsy & eyes, liver \\
\hline 12 & 1988 & Rauf $\mathrm{AF}^{12)}$ & 50 & $\mathrm{M}$ & anorexia and abdominal pain & jejunum & + & biopsy & parotid gland, liver \\
\hline 13 & 1991 & Sakuramoto $\mathrm{M}^{13}$ & 49 & $\mathrm{~F}$ & diarrhea & ileum & + & biopsy & lingual tonsilis \\
\hline 14 & 1994 & Fleming $\mathrm{RH}^{13)}$ & 41 & $M$ & hematochezia & jejunum & + & resection & liver \\
\hline
\end{tabular}

が巻き込まれて一塊となっていたため，虫垂のみ切除 することを断念し，回盲部切除を施行した。

両疾患の共通する症状として腹痛があるが, 腹痛の 部位が腹部腫瘤と一致する部位に認めたため, 虫垂粘 液表胞腺腫による痛みと考えられ，本症例において小 腸サルコイドーシスは無症候性であると考えられた。 虫垂粘液襄胞腺腫と小腸サルコイドーシスの合併例 はわれわれの調べえた範囲では，見あたらず，本邦初 の症例と考えられた。

\section{結語}

虫垂粘液襄胞腺腫の手術を契機に発見された小腸サ ルコイドーシスの1例を経験したので, 文献的考察を 加えて報告した。

\section{文献}

1）櫻本美輪子, 江川直人, 門馬久美子他：クローン 病と鑑別が困難であったサルコイドーシスの小腸 病変の 1 例. Gastroenterol Endosc 35:10231030, 1993

2) Mayock RL, Bertrand P, Morrison CE, et al : Manifestations of Sarcoidosis. Analysis of 145 patients, with a review of nine series selected from the literature. Am J Med $35: 67-89,1963$

3) Watson CJ, Rigler LG, Wangensteen $\mathrm{OH}$, et al : Isolated sarcoidosis of the small intestine simulating non-specific ileo-jejunitis. Gastroenterology $4: 30-52,1945$

4) Becker WF, Coleman WO: Surgical significance of abdominal sarcoidosis. Ann Surg 153 : 987-995, 1961
5) Delor CJ : Sarcoidosis and collagen diseases of the gastrointestinal tract. Am J Gast 38 : 547554,1962

6) Miyamato $C$, Nomura $S$, Kudo $E$, et al: An autopsy of sarcoidosis in the intestinal canal. Bull Osaka Med Sch 18:48-53, 1972

7）松田康雄, 藤井義敬, 秦 石賢他: 胃サルコイド ージスにて胃切除後, 回盲部に同病変の出現をみ た 1 症例. 日臨 $38: 228-233,1980$

8）杉浦勇人, 佐久間温己, 松崎正明他：スキルスと 診断困難であった胃サルコイドーシスの 1 例. 臨 外 $38: 535-539,1983$

9) Sprague R, Harper S, McClain S, et al: Disseminated gastrointestinal sarcoidosis. Case report and review of the literature. Gastroenterology $87: 421-425,1984$

10）伊藤隆夫, 田中千凱, 松村幸次郎他：サルコイド ーシスを伴った空腸平滑筋肉腫の 1 例. 外科診療 27 : 1092-1096, 1985

11) Bulger K, O'Riordan M, Purdy S, et al : Gastrointestinal sarcoidosis resembling Crohn's disease. Am J Gast 83 : 1415-1417, 1988

12) Rauf AF, Davis $P$, Levendoglu $H$, et al : Sarcoidosis of the small intestine. Am J Gast 83 : 187-189, 1988

13) Fleming $R H$, Nuzek M, McFadden DW : Small intestinal sarcoidosis with massive hemorrhage: Report of a case. Surgery $115: 127-$ 131, 1994 
14) Rokitansky KF : Beitrage zu den Erkrankungen des Wurmfortsatzes. Wiener Medizinische Presse $26: 428-435,1866$

15）笠原 洋, 中尾稀一,上田省三他：良性の虫垂粘 液缼胞. 近幾大医誌 $9: 459-467,1984$
16）長谷川誠，永嶌嘉嗣，和田信昭他：虫垂粘液豪胞 腺腫の 1 例. 日臨外会誌 $60: 1854-1861,1999$

17）樋田泰浩, 池田浩之, 金子敏文他：虫垂粘液亯胞 の 3 例。日臨外医会誌 $58: 1049-1052,1997$

\title{
A CASE OF SARCOIDOSIS OF THE SMALL INTESTINE PRESENTED WITH A MUCINOUS CYSTADENOMA OF THE APPENDIX
}

\author{
Shun-ichi OSADA, Tetsuya TAKAHASHI, Tadao FUKUSHIMA and Toshimichi TAKAHASHI \\ Department of Surgery, Yokohama Ekisaikai Hospital
}

An 80 -year-old man who had been suffered from abdominal pain since September 2000 was referred to the hospital with a tentative diagnosis of a tumor on the ileocecal region. On palpation an elastic tumor $5 \mathrm{~cm}$ in diameter was palpable in the right lower quadrant of the abdomen. Abdominal CT scan visualized a low density tumor with homogeneous inner part. Ileocecal tumor was diagnosed and the patient was operated on. At laparotomy, there existed a tumor arisen in the appendix and a linear ulcer covering the entire circumference of the ileum about $70 \mathrm{~cm}$ distal from the Bauhin valve. A ileocecal resection, including appendical tumor and ileal ulcer, was performed. Pathological diagnosis was mucinous cystadenoma of the appendix and sarcoidosis of the small intestine.

Since sarcoidosis of the small intestine has rarely been reported so far, we present an analysis of cumulated cases of the disease together with some bibliographical comments. 